\title{
LABEL LEGIBILITY INFLUENCED BY DIFFERENT NUMBER OF WHITE INK LAYERS
}

\author{
Klementina Možina, Igor Majnarić, Blaž Rat
}

Original scientific paper A different number of white ink layers printed with the inkjet technology can influence the legibility of prints. Therefore, we tested how to achieve best legibility of printed text and labelling information, considering the changes in colorimetric and typographic properties. The prints were made with an inkjet printer and three different numbers of white ink layers were used. Three different typefaces in four different sizes, appropriate for labelling, were tested. The colour differences were determined colorimetrically and the differences in the typographic tonal density of typefaces were measured with an image analysis. The legibility research was performed with the help of observers who read the printed text in the combination of white ink on black paper and black ink on white paper. The results led to the conclusion that with regard to the colorimetric and typographic quality and effectiveness, the legibility was the best at two layers of white ink.

Keywords: colorimetric properties; inkjet; labelling; legibility; packaging design; typography

Čitljivost etiketnih deklaracija ostvarenih s višebrojnim nanošenjem bijele boje

Izvorni znanstveni članak

Različit broj otisnutih slojeva bijele boje utječe na čitljivost otisaka. U ovom radu testirana je mogućnost postizanja najbolje čitljivosti otisnutog teksta na etiketi, zajedno sa analizom tipografskih svojstava i ostvarenih kolornih promjena. Otisci otisnuti na UV tintnom pisaču imaju mogućnost ostvarivanja većeg broja istih separacija (tri sloja bijele). Pritom su varirana tri tipa i četiri veličine pisma (karakteristična za etiketne deklaracije). Kolorne promjene su određene kolorimetrijski, te izračunom tipografske optičke gustoće slova primjenom slikovne analize. Ispitivanje čitljivosti je izvršena uz pomoć ispitanika koji su čitali tekst u kombinaciji: bijela podloga - crni tekst i crna podloga - bijeli tekst. Rezultati pokazuju da bez obzira na ostvarene kolorimetrijske promjene i različitu kvalitetu tipografske reprodukcije, najbolja čitljivost je ostvarena tiskom u dva sloja.

Ključne riječi: čitljivost; dizajn ambalaže; etiketiranje; kolorne promjene; tintni (inkjet); tipografija

\section{Introduction}

The impact of digital media is growing daily; nevertheless, conventional materials like paper still play an important role in our lives. Furthermore, packaging used to have only a small impact on our purchase decisions - bought goods were wrapped into paper or cardboard merely for their protection, whereas these days, the packaging and its appearance, respectively, can encourage potential buyers to either purchase the product or not $[1,2]$. Special, e.g., coloured, relief and pattern, papers are often used [3]. Packages also need labels to communicate how to use, transport, recycle or dispose of the package or product. Graphic communication in primary (selling) packaging is hence very important [4, 5]. While the communication on paper demands from the observer to translate symbols into meaning, legibility refers to how easily this process is performed. To enable reading, the text must have three properties, namely [6, 7]:

- visibility for a clear image of adequate size to be perceived in real time;

- recognisability or perceptibility of letters and words which make up the text. This is affected by factors such as type style and form, as well as by the person's reading skills;

- comprehension, which is affected not only by the text content but also by its visibility and perceptibility, and by the observer's verbal capacity.

Legibility is effectiveness of the visual presentation of information. A number of studies on legibility highlight its importance $[8 \div 11]$. There are some typeface characteristics to be taken into consideration to make a text more legible. For a small type size, it is known that the differences in stroke width and typographic tonal density (or typographic tonality) are significant $[12,13]$, influencing text legibility. The aim of our research was to establish how big these influences really are, even though a number of other typographic characteristics needs to be observed in order to make a text more legible, i.e., distinctive character features (counter shape), x-height, ascender, descender, serifs, contrast (stroke weight), set width, type size, leading (i.e., space between lines) etc. [6, $7,14,15]$. The $\mathrm{x}$-height is the distance between the baseline and the midline of an alphabet, which is normally the height of unextended lowercase letters (e.g. $a, c, m, r$, $u, x)$. It also refers to its visual angle which affects the speed of reading [16]. An ascender is the distance between the midline and the cap line or ascender line (e.g., upper parts of letters $b, d, h, k$ are in ascender). A descender is the distance between the baseline and the descender line (e.g., lower parts of letters $p, q, y$ are in descender). A small stroke added to the beginning or end of the main stroke of a letter is called a serif. Serifs at different typeface styles differ according to their shape and size. The contrast depends on the difference between thick and thin strokes of a given letter. Set width defines the width of a letter (e.g., the same typeface style and the same size can have different letter width) [17, 18]. The focus was put on the type sizes $6,10,12$ and especially 8 pt, which are most commonly used for labelling declarations, e.g., ingredients, instructions. A precise type size, however, depends on the $\mathrm{x}$-height of a typeface typefaces with larger but moderate $\mathrm{x}$-heights are generally more legible at small sizes $[6,14 \div 16,19]$.

In typography design, it is also useful to be familiar with the typographic tonal density of different typographic elements, which refers to the relative blackness or shades of grey of type on a page. It can be 
expressed as the relative amount of ink per square centimetre, pica or inch [20]. The changes in various type features can create variations in typographic tonal density $[6,7,21,22]$. Typefaces with larger counters trap a larger amount of white space in the enclosed spaces of letters. The cumulative effect decreases typographic tonal density. A thicker stroke width creates more ink per area $[17,18,21,22]$.

The inkjet technology as one of non-impact printing (NIP) technologies has recently become important and widely used in many different areas, especially for professional use $[12,23]$. It is also convenient to use the inkjet technology for special effects, e.g., more layers of ink or varnish $[24 \div 27]$. While there are recommendations about the quality of CMYK inkjet prints [28], there are no available recommendations or standards about the required quality for using white ink in the inkjet technology, which could be used for special effects in graphic design for designing packaging, posters, flyers etc.

Therefore, the purpose of this study was to examine the influence of a different number of white ink layers on legibility, and typographic as well as colorimetric properties of labels in order to establish an appropriate typeface style and the number of white ink layers on black paper for a good quality of a packaging declaration.

\section{Methods}

In the research, we wanted to establish how many ink layers printed with a modern digital printing technology enable the best quality of printed information. Furthermore, we wanted to find out which typeface family contributes to better legibility. Therefore, we compared the legibility research of different layers of white ink on black paper with the legibility of black prints on white paper.

\subsection{Paper properties}

The prints for the research were made on high gloss black paper, the cast coated side was surface coloured with metal pigments and coated with water-based varnish (P1), as it is stated in its declaration. This kind of paper is commonly used in packaging design. We also used white paper (P2) with a semi-mat coated declaration. This paper grade is normally used in the book production [25], as it enables good printability and therefore good text legibility.

Prior to the printing, the basic surface and optical properties of paper were measured. Paper grammage was measured according to the ISO 536 standard [29], while paper thickness was measured according to the ISO 534 standard [30]. Density was calculated according to the ISO 534 standard [30]. Specific volume is related to porosity, rigidity, hardness and strength, and influences several physical and optical properties of paper. The measurements were performed according to the ISO 534 standard [30]. The measurement of airflow was used to describe paper porosity, which was tested according to the Bendtsen method in line with the ISO 5636-3 standard [31]. The water absorption of paper was measured with the Cobb method in accordance with the ISO 535 standard [32], where the duration of the test was 60 seconds $\left(\mathrm{Cobb}_{60}\right)$. Specular gloss was performed according to the ISO 8254-1 standard [33], where it is a ratio of the luminous flux reflected by the test surface at the angle of standard specular reflection. Opacity describes the amount of light transmitted through paper and was measured with regard to the ISO 2471 standard [34]. Before determining paper characteristics, the samples were conditioned according to the ISO 187 standard [35]. The properties measured on the felt side of two papers $(\mathrm{P} 1, \mathrm{P} 2)$ are presented in Tab. 1 .

Table 1 Properties of used papers (P1, P2)

\begin{tabular}{|l|c|c|}
\hline \multicolumn{1}{|c|}{ Properties } & P1 & P2 \\
\hline Grammage $\left(\mathrm{g} / \mathrm{m}^{2}\right)$ & 251,20 & 92,30 \\
\hline Thickness $(\mathrm{mm})$ & 0,302 & 0,075 \\
\hline Density $\left(\mathrm{kg} / \mathrm{m}^{3}\right)$ & 832 & 1222,93 \\
\hline Specific volume $\left(\mathrm{cm}^{3} / \mathrm{g}\right)$ & 1,21 & 0,82 \\
\hline Porosity $(\mathrm{ml} / \mathrm{min})$ & 0 & 2 \\
\hline Water absorption $\left(\mathrm{g} / \mathrm{m}^{2}\right)$ & 0,99 & 29,80 \\
\hline Gloss $(\%)$ & 90,40 & 28,10 \\
\hline Opacity $(\%)$ & 100,00 & 88,01 \\
\hline
\end{tabular}

\subsection{Typographic and colorimetric properties of prints properties}

White and black prints were made with a non-impact printing (NIP) technology: LEC-300 (Roland, USA), which uses the piezo inkjet technology. Black prints were made with an original cartridge. For white prints, we used ECO-UV ink, which comprises titanium oxide $\left(\mathrm{TiO}_{2}\right)$ [36]. The application of $\mathrm{TiO}_{2}$ ensures very good light fastness $[37 \div 39]$. White prints differ in the number of printed layers of ink, i.e., one, two and three layers (L1L3).

Three different typefaces with similar typographic characteristics, yet with differences in stroke width were tested, i.e., one old-style (Palatino) [17, 18, 40], one transitional typeface (Times) $[17,18,40]$ and one modern typeface (Blaznic) $[17,18,40]$ in four different sizes, i.e., $6,8,10$ and $12 \mathrm{pt}$. On each print, five field intensities were printed, i.e., of $100 \%, 80 \%, 60 \%, 40 \%$ and $20 \%$. The test form was designed with the program Adobe InDesign, exported and used as a PDF file, which ensured a unified appearance of the form on various operation systems and in consequence, on the print.

The CIE $L^{*} a^{*} b^{*}$ parameters of white prints were measured with a spectrophotometer eXact (X-rite, USA) in accordance with the ISO 13655 standard [41], using the D50 standard illumination, $2^{\circ}$ standard observer, instrument geometry $45 / 0$ and mode M1. The colour difference $\left(\Delta E_{00}\right)$ among different numbers of printed ink layers was calculated using the CIE $\Delta$ E2000 $L^{*} a^{*} b^{*}$ equation for colour differences [42, 43]:

$\Delta E_{00}=\sqrt{\left(\frac{\Delta L^{\prime}}{k_{\mathrm{L}} S_{\mathrm{L}}}\right)^{2}+\left(\frac{\Delta C^{\prime}}{k_{\mathrm{C}} S_{\mathrm{C}}}\right)^{2}+\left(\frac{\Delta H^{\prime}}{k_{\mathrm{H}} S_{\mathrm{H}}}\right)^{2}+R_{\mathrm{T}}\left(\frac{\Delta C^{\prime}}{k_{\mathrm{C}} S_{\mathrm{C}}}\right) \cdot\left(\frac{\Delta H^{\prime}}{k_{\mathrm{H}} S_{\mathrm{H}}}\right)},(1)$

where:

$\Delta L^{\prime}$ is difference in lightness,

$\Delta C^{\prime}$ is difference in chroma,

$\Delta H^{\prime}$ is difference in hue, 
$R_{\mathrm{T}}$ is correction of ellipsoid orientation in the blue region,

$k_{\mathrm{L}}, k_{\mathrm{C}}, k_{\mathrm{H}}$ are parameter factors which are under referential conditions set to 1 , and

$S_{\mathrm{L}}, S_{\mathrm{C}}, \mathrm{S}_{\mathrm{H}}$ are factors representing correction of visual disunity of the colour space CIE $L^{*} a^{*} \mathrm{~b}^{*}$ and defining the ellipsoid half-axes.

The typographic tonal density of typefaces was measured with an image analysis (ImageJ) [44, 45]. This software gives the opportunity to measure, analyse and provide output values, e.g., area, number of particles, circularity and percentage of coverage [44, 45]. All the measured samples were of the same size, i.e., $1795 \times$ 1850 pixels (600 pixels/inch), which is equal to $76 \times 78$ $\mathrm{mm}$.

\subsection{Legibility}

Different texts of popular science were printed in different typefaces in the size of $8 \mathrm{pt}$ on both used papers. On paper P1, the texts were printed in three different white ink layers (L1-L3), whereas on paper P2, the texts were printed with one layer of black ink (L1). The length of the texts was between 130 and 200 words. The time needed to read 500 characters (in seconds) was calculated, based on the time required for the reading of the whole text. Additionally, the proportion of correct responses to multiple-choice questions (with two-response alternatives) was examined.

The observers $(N=20)$ were aged between 18 and 30 years $(M=25,30$ years, $S D=4,8)$ with normal or corrected-to-normal vision. They read the texts at the same conditions of lighting and viewing distance. Each participant read all 12 texts (3 typefaces $\times 4$ samples), which were presented in random order to different participants to eliminate possible order effects.

The influence of the typeface, number of ink layers and paper grades on legibility was statistically analysed with the IBM SPSS 20 software. Two two-way analyses of variance for repeated measures with the time needed to read 500 characters as a dependent variable were performed. The first two-way analysis of variance was performed for the texts printed in a different number of layers of ink and for different typefaces on paper P1. Another two-way analysis of variance was performed for the texts printed in one layer of ink but with different typefaces, printed on both papers (P1, P2). Due to the non-sphericity of data (Mauchly's test), the GreenhouseGeisser correction was used. Statistical hypotheses were tested at 0,001 alpha error rate. Finally, one-way repeated analysis was conducted to compare the reading speeds among different typefaces on $\mathrm{P} 2$.

\section{Results and discussion}

Fig. 1 shows the differences in the thickness of different layers of ink. The microscopic photos (enlarged 400 times) made with a microscope Leica DM2500 M (Leica Microsystems, Germany) with a USB camera Dino-Eye AM423C (Dino-Lite, Brazil) show that the sample with one ink layer (L1) has minimum thickness on the measured printed layer $\left(d_{\mathrm{L} 1}=5,91 \mu \mathrm{m}\right)$; in comparison with other printing techniques, it still belongs to one extremely large ink layer. Such a printed layer is not homogeneous and can lead to deviations in the amount of $\Delta d_{\mathrm{L} 1}=1,92 \mu \mathrm{m}$. Moreover, the printed layer is highly porous, since we applied liquid UV LED inkjet ink where the concentration of $\mathrm{TiO}_{2}$ pigment is not high. When printing two ink layers (L2), the thickness of applied white ink is twice as high $\left(d_{\mathrm{L} 2}=14,13 \mu \mathrm{m}\right)$. Applying UV inkjet ink twice contributed to the thickness of the printed layer without changing its porosity. At extreme printing with three ink layers (L3), we achieved the largest experimental printing of ink $\left(d_{\mathrm{L} 3}=16,87 \mu \mathrm{m}\right)$. Although it is larger by only $\Delta d_{\mathrm{L} 3-\mathrm{L} 2}=2,73 \mu \mathrm{m}$ in the cross section, significantly lower porosity and greater compactness of the printed layer is noticeable. Due to the application of inkjet printing techniques, the homogeneity of the formed print layer is not great, which can be seen in the deviation $\Delta d_{\mathrm{L} 3}=2,09$.
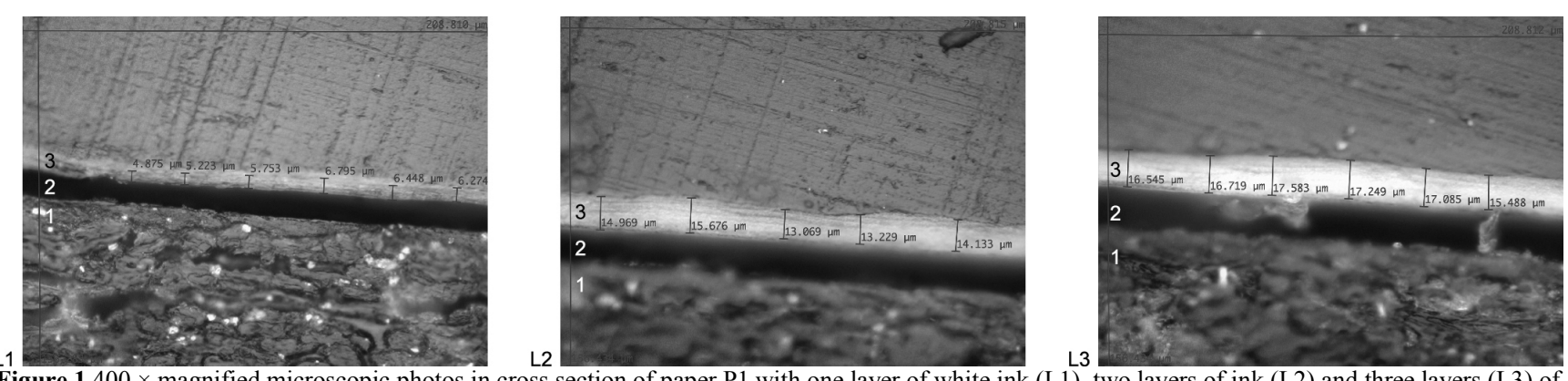

Figure $1400 \times$ magnified microscopic photos in cross section of paper P1 with one layer of white ink (L1), two layers of ink (L2) and three layers (L3) of ink, where 1 is paper base, 2 is paper coating and 3 is thickness of ink layer(s)

\subsection{Colorimetric properties of prints}

Fig. 2 shows the CIE $L^{*} a^{*} b^{*}$ parameters of white prints with $100 \%, 80 \%, 60 \%, 40 \%$ and $20 \%$ intensity (tonal value) printed with different layers (L1-L3) of white ink. The obtained results show that there are significant differences between the prints with one layer of ink (L1) and the prints with two layers of ink (L2). Experimental printing with one layer of ink gave suitable reproduction in which all white tones retained their recognizability (continuously visible reproduced screen wedge from $20 \%$ to $100 \%$ printed intensity). There were a continuous increase in lightness $\Delta L^{*}{ }_{100 \%-20 \%}=44,66$ and minimal chromatic changes (in the direction of green axis $\Delta a^{*}{ }_{100 \%-20 \%}=1,96$ and blue axis $\Delta b^{*}{ }_{100 \%-20 \%}=2,18$ ). White prints with a larger number of layers followed the characteristic curve, but only to the area of $80 \%$ printing intensity. When two layers of ink were applied, full tones generated a rapid rise in the value of lightness $\Delta L^{*}{ }_{100 \%-80 \%}=25,37$, whereby the value of chromatic 
components changed $\left(\Delta a^{*}{ }_{100 \%-80 \%}=0,02\right.$ and $\Delta b^{*}{ }_{100 \%-20 \%}$ $=3,63$ ). A further increase in ink layers (three layers of white ink) could be best described with a logarithmic function (changes were visible but without the desired effect). Three layers of ink led to smaller changes in lightness $\Delta L^{*}{ }_{100 \%-80 \%}=23,17$, and greater in chroma (chroma values are closer to the achromatic axis $\left.\Delta a^{*}{ }_{100 \%-80 \%}=0,74, \Delta b^{*}{ }_{100 \%-20 \%}=4,84\right)$.

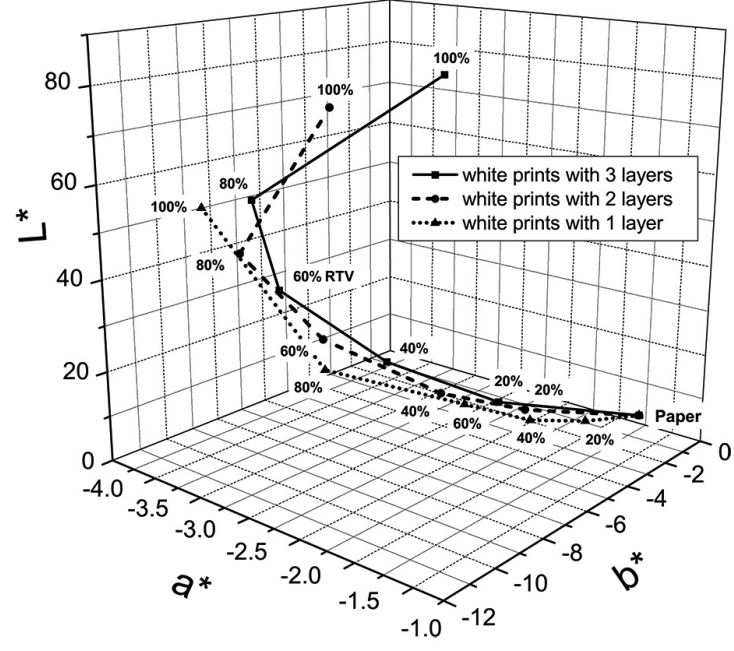

Figure 2 CIE $L^{*} a^{*} b^{*}$ parameters of white prints with $20 \%, 40 \%, 60$ $\%, 80 \%$ and $100 \%$ intensity (tone value) printed with different layers of ink (L1-L3) on paper P1

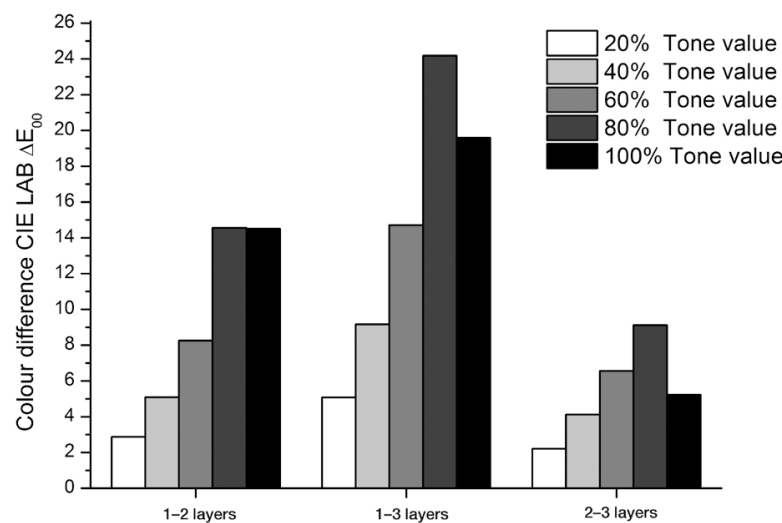

Figure 3 Colour difference $\left(\Delta E_{00}\right)$ for white prints with $20 \%, 40 \%$, $60 \%, 80 \%$ and $100 \%$ intensity (tone value) printed with different layers of ink (L1-L3) on paper P1

The colour differences $\left(\Delta E_{00}\right)$ among different numbers of printed ink layers were calculated (cf. Fig. 3). The highest colour differences were observed between the prints L1 and L3, which could be noticed with the naked eye. When applying a larger number of white ink layers, it could be seen that the higher surface tone coverage on prints showed a greater change in the colour difference value $\left(\Delta E_{00}\right)$. Therefore, a colour comparison of prints with one layer and two layers resulted in greater colour changes on white tone, which was noticed with the naked eye. The surface of $80 \%$ intensity looked as a solid tone $\left(\Delta E_{2 \mathrm{~L}-1 \mathrm{~L}}=14,51\right)$. Additional depositing of white ink (prints with three layers) generated visually greater colour changes. In relation to the printing with two layers, there were substantial colour differences: $\Delta E_{\mathrm{L} 3-\mathrm{L} 2(20 \%)}=2,2$, $\Delta E_{\mathrm{L} 3-\mathrm{L} 2(40 \%)}=4,08, \Delta E_{\mathrm{L} 3-\mathrm{L} 2(60 \%)}=6,46, \Delta E_{\mathrm{L} 3-\mathrm{L} 2(80 \%)}=$ $9,67, \Delta E_{\mathrm{L} 3-\mathrm{L} 2(100 \%)}=5,08$. The most noticeable colour difference was achieved in the area with $80 \%$ intensity. The reason lies in an inaccurate inkjet system, which resulted in a complete closure of the screened area and its transformation into a solid tone. Accordingly, we can expect that an increased number of white layers of ink will further lead to visually perceived colour changes (increased colour difference). However, they will not be as registered in the darker image areas as in the mediumtone areas (60\% intensity).

a)
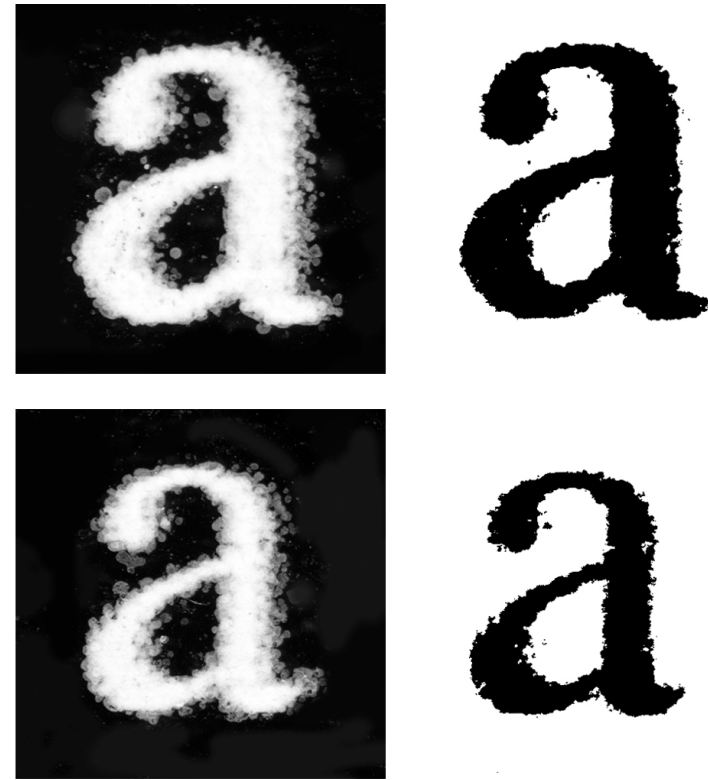

b)
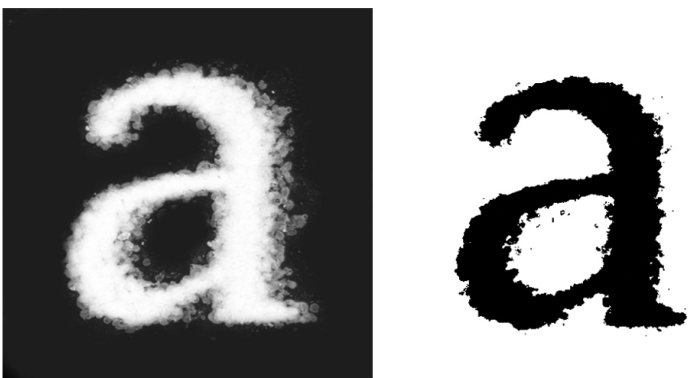

Figure $420 \times$ magnified letter "a" ( $8 \mathrm{pt})$ in different typefaces $((\mathrm{a})$ Blaznic, (b) Times, (c) Palatino) with their evident differences (i.e., stroke width, counter shape, size and shape of serifs), and their binary picture, which is base for image analysis

\subsection{Typographic properties of prints}

The typographic tonal density (TTD) of each typeface, each in different size, was measured on white and black prints. The magnified letters "a" in three different typefaces and their binary pictures, used as the base for image analyses, e.g., for measuring TTD, are presented in Fig. 4, where some basic design differences among letters are seen. The white prints of different ink layers with typographic tonal density and their differences in typographic tonal density are seen in Fig. 5-7. The TTD values of samples $(\mathrm{P} 1, \mathrm{~L} 1 ; \mathrm{P} 2, \mathrm{~L} 1)$ of the studied typeface, $8 \mathrm{pt}$ in size, are presented in Tab. 2.

The results show higher TTD at the modern typeface Blaznic (cf. Tab. 2, Fig. 5) due to the wider stroke width of letters. The lowest TTD was observed at the transitional typeface Times (cf. Tab. 2, Fig. 6); however, the measured values were very similar to those of the old-style typeface Palatino (cf. Tab. 2, Fig. 7). The Palatino letters have a big 
counter size, and the difference between thick and thin strokes is not substantial, while the Times letters have smaller counter size, wider thick strokes and thinner thin strokes than the old-style typefaces.

According to the results (cf. Fig. $5 \div 7$ ), the number of ink layers is important, as the major differences in TTD are among the printed number of ink layers. Evident differences can be seen between one layer of ink, which gave on average at all used typefaces the lowest TTD, and the other two examples of ink layers. Comparing the printed typefaces, the most noticeable differences appeared above all at the typefaces of the smallest size $(6 \mathrm{pt})$ and the least noticeable at the largest tested size (12 pt). The typefaces in smaller type sizes are much more affected by too much or too little of ink used.

While comparing the printing quality of papers and inks used in this study, a combination of white ink on black samples (P1) gave much lower TTD at the one layer of ink from the conventional combination of one layer black ink on white samples (P2) (cf. Tab. 2).

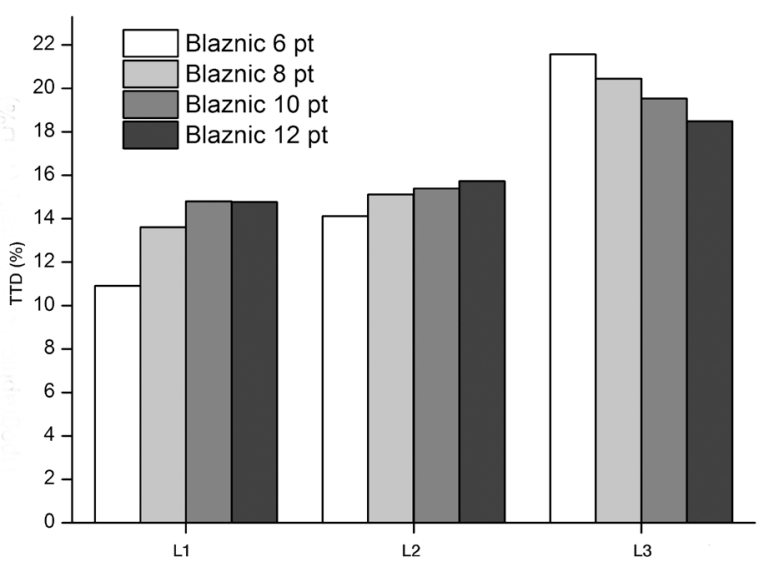

Figure 5 Typographic tonal density (TTD) of tested typeface Blaznic in sizes $6,8,10$ and $12 \mathrm{pt}$ printed on paper P1 with different layers of white inks (L1-L3)

Table 2 Value of typographic tonal density (TTD) of tested typefaces in size $8 \mathrm{pt}$ for prints on different papers (P1, P2), printed with one layer of ink (L1)

\begin{tabular}{|c|c|c|}
\hline \multirow{2}{*}{ Typeface } & \multicolumn{2}{|c|}{ TTD (\%) } \\
\cline { 2 - 3 } & P1 & P2 \\
\hline Blaznic & 13,41 & 25,95 \\
\hline Times & 10,17 & 22,46 \\
\hline Palatino & 10,67 & 22,76 \\
\hline
\end{tabular}

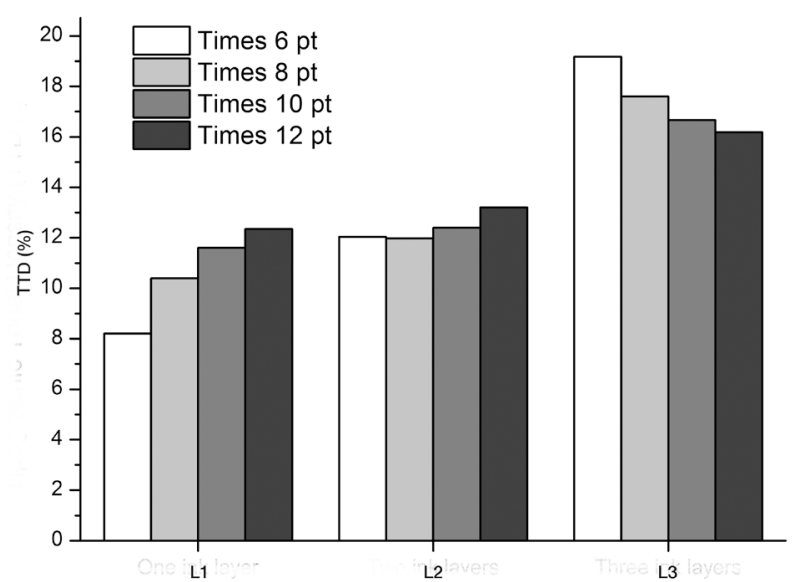

Figure 6 Typographic tonal density (TTD) of tested typeface Times in sizes $6,8,10$ and $12 \mathrm{pt}$ printed on paper P1 with different layers of white inks (L1-L3)

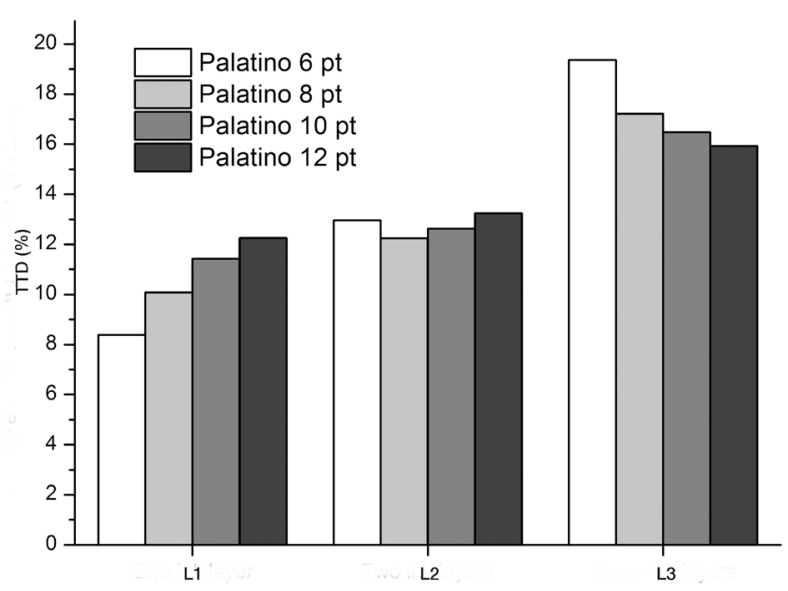

Figure 7 Typographic tonal density (TTD) of tested typeface Palatino in sizes $6,8,10$ and $12 \mathrm{pt}$ printed on paper P1 with different layers of white inks (L1-L3)

\subsection{Legibility of prints}

Fig. 8 and 9, and Tab. 3 show the influence of the used typefaces at the $8 \mathrm{pt}$ size, number of ink layers and papers on the speed of reading and number of correct responses.

According to the results (cf. Fig. 8), the reading speed was the fastest at the samples in the Palatino typeface ( $M$ $=3,92 \mathrm{~s}, S D=0,56)$ and the slowest at the samples in the Blaznic typeface $(M=37,61 \mathrm{~s}, S D=0,82): F(1,466$; $27,845)=49,485, p<0,001, M S E=279,696$. The same was observed when we took into consideration a different number of ink layers; the texts with Palatino were read the fastest and the texts with Blaznic were read the slowest (cf. Fig. 8). The Palatino letters have a big counter size, and the difference between thick and thin strokes is not substantial; this became important when more than one ink layer was used. The main effect of the number of printed ink layers was statistically significant: $F(1,171$; $22,253)=50,729, p<0,001, M S E=95,705$. The reading speed was the most effective at the prints of two ink layers $(M=34,93 \mathrm{~s}, S D=0,56)$, regardless of the used typeface. In the case of one layer $(M=35,73 \mathrm{~s}, S D=$ $0,62)$ or three layers of ink $(M=36,85 \mathrm{~s}, S D=74)$, the reading speed was slower. The mean differences between all typefaces and numbers of ink layers were statistically significant at $p<0,001$. The interaction between the typeface and the number of ink layers was not statistically significant, $p=0,074$.

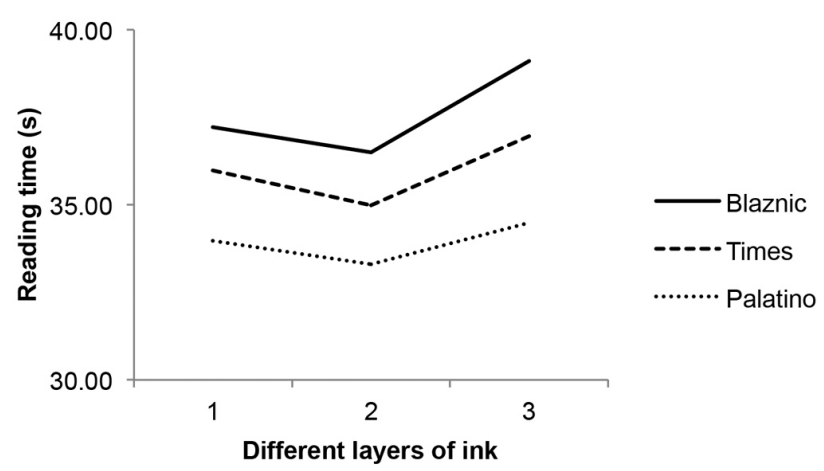

Figure 8 Time (s) needed to read 500 characters on samples with different typefaces ( $8 \mathrm{pt}$ in size), printed on paper P1 with different layers of white inks (L1-L3) 
When comparing the answers at different layers of ink, the number of correct responses increased with the texts printed in two layers (from $90 \%$ to $95 \%$ ), whereas the number of correct responses decreased with the texts printed in one layer (from $85 \%$ to $90 \%$ ) or three layers (from $80 \%$ to $90 \%$ ) of ink (cf. Tab. 3).

Table 3 Percentage of correct responses to two-alternative questions on different papers (P1, P2) and different printed layers of ink (L1-L3)

\begin{tabular}{|c|c|c|c|c|}
\hline \multirow{3}{*}{ Typeface } & \multicolumn{4}{|c|}{ Correct responses (\%) } \\
\cline { 2 - 5 } & \multicolumn{3}{|c|}{ P1 } & P2 \\
\cline { 2 - 5 } & L1 & L2 & L3 & L1 \\
\hline Blaznic & 85 & 95 & 80 & 85 \\
\hline Times & 90 & 90 & 90 & 90 \\
\hline Palatino & 85 & 90 & 80 & 90 \\
\hline
\end{tabular}

While comparing different papers and inks used in one layer (cf. Fig. 9), the average reading speed was slower with the prints made on P1 than with the prints made on P2: $F(1 ; 19)=86,194, \quad p<0,001, M S E=$ 317,688 . The TTD of prints made on P2 was much higher than on the prints made on P1 (cf. Tab. 2). Furthermore, the average reading speed was influenced by different typefaces: $F(1,31 ; 24,92)=19,280, p<0,001, M S E=$ 60,406 , in the case of the Blaznic typeface being the slowest. However, the Post Hoc multiple comparison of the mean differences between Blaznic and Times $(35,02 \pm$ $0,59 \mathrm{~s}$ vs. $34,23 \pm 0,55 \mathrm{~s})$, and Blaznic and Palatino $(35,02$ $\pm 0,59 \mathrm{~s}$ vs. $33,04 \pm 0,60 \mathrm{~s})$ were statistically significant at $p<0,05$ (with Sidak correction at level $p<0,001$ ), regardless of the sample of paper used. The mean differences between Times and Palatino were not statistically significant $(p=0,001)$. The interaction between the typeface and the sample of paper was also statistically significant, $F(1,402 ; 26,637)=19,489$, $p<0,001, M S E=23,411$. One-way repeated analysis of variance revealed that the typefaces printed in the conventional combination of black prints on white paper (P2) with one layer of ink gave the opportunity for shorter reading time, where 500 characters in Blaznic were read on average in $32,82 \mathrm{~s}(S D=2,32)$, in Times in $32,48 \mathrm{~s}$ $(S D=2,33)$ and in Palatino in $32,11 \mathrm{~s}(S D=3,06)$ (cf. Fig. 9).

Comparing the answers at different papers and used inks, the number of correct responses is similar (from 85 $\%$ to $90 \%$ ) (cf. Tab. 3)

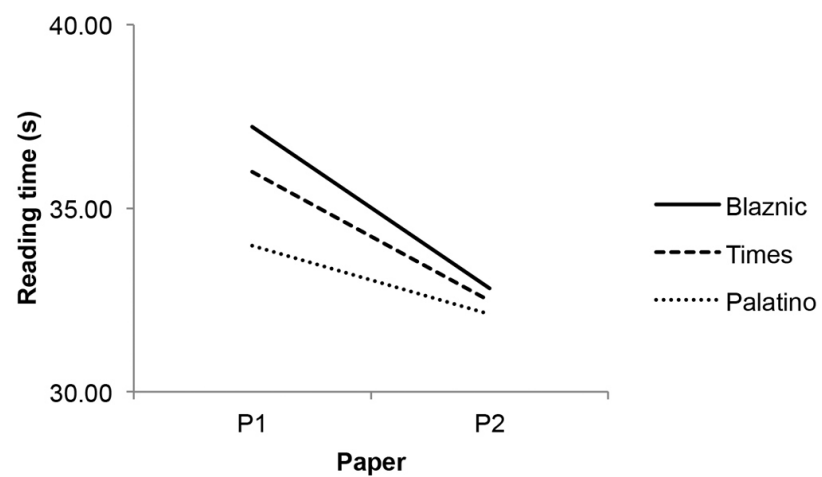

Figure 9 Time (s) needed to read 500 characters on samples with different typefaces $(8 \mathrm{pt}$ in size), printed on different papers $(\mathrm{P} 1, \mathrm{P} 2)$ with one layer of ink

\section{Conclusions}

As it is necessary to pay attention to graphic design in packaging, it is necessary to take into consideration the printing quality and legibility of the declaration on labelling.

The goal of the research was to determine the printing quality and legibility of white ink used on black paper. The results of the study show that it is necessary to consider the chosen typeface and its size to ensure information legibility. The obtained results reveal that the number of ink layers is of importance for the legibility of text, as well as for its design effect.

Choosing an appropriate typeface is also important to achieve good quality of information, and to ensure legibility and higher speed of reading. The old-style typeface Palatino gives the best legibility results among the tested typefaces. Its added value lies in the width of counter shape, ensuring short reading times and good legibility results. Due to its design, the typeface is very well depicted, stable and legible in smaller sizes, printed with more than one layer of ink.

The text legibility is influenced by typographic tonal density, which varies with the used typeface, its size and especially with the used number of ink layers. The colorimetric and typographic (TTD) results are the best at two layers of white ink as are also the legibility and design effect.

\section{References}

[1] Bix L.; Rifon N.; Lockhart H.; de la Fuente J. The Packaging Matrix: Linking Package Design Criteria to the Marketing Mix. // IDS Packaging. 2008. URL: http://www.idspackaging.com/Common/Paper/Paper_47/Pd fImge.pdf. (8. 12. 2014).

[2] Clement J. Visual influence on in-store buying decisions: an eye-track experiment on the visual influence of packaging design. // Journal of Marketing Management, 23, (2007), pp. 917-928. DOI: 10.1362/026725707X250395

[3] Twede D. E.; Selke S. E. M. Cartons, crates and corrugated board: handbook of paper and wood packaging technology.DEStech Publications, Lancaster, 2005.

[4] Robertson G. L. Food Packaging: Principles and Practice. CRC press, Boca Raton, 2012.

[5] Gomes T.; Hurley R. A.; Duchowski A.; Darby D.;Ouzts A. The Effect of Full Body versus Partial Body Graphic Labelling on Beverage Packaging. // Packaging Technology and Science. 4, (2014). DOI: 10.1002/pts.2070

[6] Možina K. Zgodovinski razvoj knjižne tipografije [doctoral dissertation]. University of Ljubljana, Ljubljana, 2001.

[7] Reynolds L. Legibility of Type. // Baseline. 10(1988), pp. 26-29.

[8] ISO 11799: Information and documentation - Document storage requirements for archive and library materials. ISO, Geneva, 2003.

[9] Bix L.; Lockhart H.; Selke S.; Cardoso F.;Olejnik M. Is xheight a better indicator of legibility than type size for drug labels? // Packaging Technology and Science. 16, (2003), pp. 199-217. DOI: 10.1002/pts.625

[10] Tai Y.-C.; Sheedy J.; Hayes J. Effect of letter spacing on legibility, eye movements, and reading speed. // Journal of Vision. 6, (2006). DOI: 10.1167/6.6.994

[11] McMonnies, C. W.; Ho, A. Letter legibility and chart equivalence. // Ophthalmic Physiology Optics. 20, (2000), pp. 142-152. DOI: 10.1016/S0275-5408(99)00047-2 
[12] Možina, K.; Medved, T.; Rat, B.; Bračko, S. Influence of Light on Typographic and Colorimetric Properties of Ink Jet Prints. // Journal of Imaging Science and Technology. 54, (2010), pp. 060403-1-060403-8.

[13] Rat, B.; Možina, K.; Bračko, S.; Podlesek, A. Influence of Temperature and Humidity on Typographic and Colorimetric Properties of Ink Jet Prints. // Journal of Imaging Science and Technology. 55, (2011), pp. 0506071-050607-8.

[14] Gaultney, V. Balancing Typeface Legibility and Economy: Practical Techniques for the Type Designer [research essay]. University of Reading, Reading, 2001.

[15] Tracy, W. Letters of Credit: A View of Type Design. David R. Godine, Boston, 2003.

[16] Legge, G. E.; Bigelow, C. A. Does print size matter for reading? A review of findings from vision science and typography. // Journal of Vision. 11, (2011). DOl: 10.1167/11.5.8

[17] Možina, K. Knjižna tipografija. University of Ljubljana, Ljubljana, 2003.

[18] Bringhurst, R. The Elements of Typographic Style. Hartley \& Marks, Point Roberts, 2002.

[19] Wilkins, A.; Cleave, R.; Grayson, N.; Wilson, L. Typography for children may be inappropriately designed. // Journal of Research in Reading. 32(2009), pp. 402-412. DOI: 10.1111/j.1467-9817.2009.01402.x

[20] Keyes, E. Typography, color, and information structure. // Technical Communication. 4, (1993), pp. 638-654.

[21] Možina, K.; Černič, M.; Demšar, A. Non-destructive methods for chemical, optical, colorimetric and typographic characterisation of a reprint. // Journal of Cultural Heritage. 8, (2007), pp. 339-349. DOI: 10.1016/j.culher.2007.03.005

[22] Možina, K.; Možina, K.; Bračko, S. Non-invasive methods for characterisation of printed cultural heritage. // Journal of Cultural Heritage. 14, (2013), pp. 8-15. DOl: 10.1016/j.culher.2012.02.012

[23] Piezo Institute [Internet]. 2014. URL: http://www.piezoinstitute.com. (27. 12. 2014).

[24] Majnarić I.; Bolanča Z.; BolančaMirković I. The influence of the accelerated ageing on the black screen element of the Electroink prints. // Journal of Physics: Conference Series 231. 012018(2010), pp. 1-10.

[25] Kipphan, H. Handbook of print media: technologies and production methods. Springer, Heidelberg, 2001. DOl: 10.1007/978-3-540-29900-4

[26] Majnarić, I.; Hladnik, A.; Muck, T.; Bolanča Mirković, I. The Influence of Ink Concentration and Layer Thickness on Yellow Colour Reproduction in Liquid Electrophotography Toner. // Technical Gazette. 22, 1(2015), pp. 145-149. DOl: 10.17559/tv-20140321230455

[27] Majnarić, I.; Bolanča Mirković, I.; Golubović, K. Influence of UV Curing Varnish Coating on Surface Properties of Paper. // Technical Gazette. 19, 1(2012), pp. 51-56.

[28] Krasushaar, A. PSD: Process Standard Digital Handbook. Fogra Graphic Technology Research Association, Munich, 2014.

[29] ISO 536: Paper and board: Determination of grammage. ISO, Geneva, 1995.

[30] ISO 534: Paper and board: Determination of thickness and apparent bulk density or apparent sheet density. ISO, Geneva, 1997.

[31] ISO 5636-3: Paper and board: Determination of air permeance (medium range) - Bendtsen method. ISO, Geneva, 1992.

[32] ISO 535: Paper and board: Determination of water absorptiveness - Cobb method. ISO, Geneva, 1991.

[33] ISO 8254-1: Paper and board: Measurement of specular gloss - Part $1: 75^{\circ}$ gloss with a converging beam, TAPPI method. ISO, Geneva, 2009.
[34] ISO 2471: Paper and board: Determination of opacity (paper backing) - Diffuse reflectance method. ISO, Geneva, 1998.

[35] ISO 187: Paper, board and pulps: Standard atmosphere for conditioning and testing and procedure for monitoring the atmosphere and conditioning of samples. ISO, Geneva, 1990.

[36] Material Safety Data Sheet, for immediate UV ink-curing two UV LED lamps are being used. Roland DG Corporation, Nauheim, 2009, p. 150.

[37] Majnarić, I.; Golubović, K.; Bolanča, S.; Modrić, D. Analiza kolorne reprodukcije kreirane primjenom višeslojnog nanašanja bjele boje na PVC foliju. // Proceedings of International conference MATRIB / Zagreb / 2010, p. 268-279.

[38] Puhalo, M.; Slugić, A.; Majnarič, I. Light Accelerated Ageing of White Ink Printed in UV LED Inkjet Technique. $/ / 17^{\text {th }}$ International Conference on Printing, Design and Graphic Communications BlažBaromić / Zagreb, 2013, pp. 457-469.

[39] Slugić, A.; Puhalo, M.; Majnarić, I.; Bolanča Mirković, I.; Rehakova, M. The Influence of NOx on the Stability of the White Colored Inkjet Prints. // Proceedings of Conference Wood Pulp \& Paper Polygrafia Academica / Bratislava, 2014, pp. 140-145.

[40] McLean, R. The Thames and Hudson Manual of Typography. Thames and Hudson, London, 1996.

[41] ISO 13655: Graphic technology: Spectral measurement and colorimetric computation for graphic arts images. ISO, Geneva, 1996.

[42] Colorimetry. // Publ CIE. 15(2004), pp. 20-22.

[43] Luo, M. R.; Cui, G.; Rigg, B. The Development of the CIE 2000 Colour - Difference Formula: CIEDE2000. // Color Research and Application. 26, (2011), pp. 340-350. DOI: 10.1002/col.1049

[44] National Institutes of Health. URL: http://rsb.info.nih.gov/ij/. (15. 01. 2015).

[45] Stanić, M.; Lozo, B. Walters, P. J. Reproduction in ThreeDimensional Ink Jet Printing. // Journal of Imaging Science and Technology. 54, (2010), pp. 060201-1-060201-7.

\section{Authors' addresses}

\author{
Assoc. prof. dr. sc. Klementina Možina \\ University of Ljubljana, \\ Faculty of Natural Sciences and Engineering, \\ Snežniška 5, 1000 Ljubljana, Slovenia \\ E-mail: klementina.mozina@ntf.uni-lj.si
}

Assist. prof. dr. sc. Igor Majnarić

University of Zagreb, Faculty of Graphic Arts, Getaldićeva 2, 10000 Zagreb, Croatia

E-mail: imajnari@grf.hr

\section{Dr. sc. Blaž Rat}

University of Ljubljana,

Faculty of Natural Sciences and Engineering,

Snežniška 5, 1000 Ljubljana, Slovenia

E-mail: blaz.rat@ntf.uni-lj.si 